\title{
An Economic Analysis of Transportation Equipments at Container Terminals
}

\author{
Sung-Ho, Jung* $\cdot$ Dong-Seok, Lim** • + Ki-Chan, Nam \\ * Operations Team Manager, Hanjin Newport Company, Busan 645-520, Korea \\ † Dept. of Logistics Engineering, National Korea Maritime University, Busan 606-791, Korea \\ ** Graduate school of National Korea Maritime University, Busan 606-791, Korea
}

\begin{abstract}
The motivation of this study is the recent advancement of the Straddle Carrier (S/C). Previously Straddle Carrier (S/C) system was used focusing on container lift on/off due to its lower driving speed than that of ( $Y / T)$. Shuttle Carrier is evaluated as an upgraded Straddle Carrier. Recently, however, the driving speed of $(S / C)$ has been improved to the level of Yard Tractor and Trailer systems $(Y / T)$, which is $30 \mathrm{Km}$ per hour which makes $(S / C)$ qualified as terminal in-yard transportation equipment. This paper, therefore, aims to evaluate three types of terminal in-yard transportation equipments such as $(Y / T)$, ( $A G V)$ and the advanced $(S / C)$ from economic perspective. The results revealed that by observing the total costs of equipment, $(S / C)$ is a cheaper option than $(Y / T)$ over 20 years, and than $(A G V)$ over 6 years.
\end{abstract}

Key words : Container transportation equipment, Straddle Carrier $(S / C)$, Yard Tractor and Trailer systems $(Y / T)$, Automated Guided Vehicle (AGV), Economic Analysis

\section{Introduction}

Recently, worldwide trade has been enlarged dute to the expansion of WTO and FTA, which lead to the globalization because of the reduction of tarde barriers, lowring transportaion and communication costs, technology, and so on. Therefore shipping volume has been increased rapidly, thus increasing the freight volume in sea ports, triggering the development of new ports worldwide and then tough competition among ports.

In order to meet the expanded needs, shipping liners have launched mega-sized vessels with decreased number of calling ports and requested higher berth productivity. As a response to this, terminal operators have been introducing highly advanced handling equipments. At Busan New Port, for example, terminal operators are trying to maximize berth productivity by introducing quay cranes equipped with tandem trolly. In most of the real cases, delayed yard operation causes quay side operation to be delayed. Therefore in order to get maximum terminal productivity, efficient cargo flow at yard is requested in addition to the high quay side productivity achieved at berth.

Major container terminals use transportaion equipments such as Yard Tractor and Trailer systems (Y/T), Straddle Carrier (S/C) and Automated Guided Vehicle (AGV)
Recently, Shuttle Carrier, which is an upgraded (S/C) gets much attention. ( $\mathrm{Y} / \mathrm{T})$ is the most commonly used terminal in-yard transportation equipment. Many terminals increase their berth productivity by increasing the number of $(\mathrm{Y} / \mathrm{T})$ dispatched per quay crane. Previously, (S/C) was mainly used to stack containers than to move containers at yard due to its slower driving speed. (AGV) is adopted by a few automated container terminals, and still under discussions for its reliability and productivity, but the lowered labor cost is the main feature of (AGV). Shuttle Carrier has achieved flexibility by handling both transportation and stacking, as well as high productivity target by improving its driving speed to the level of $(\mathrm{Y} / \mathrm{T})$. It also does not require any additional handling equipment unlike $(\mathrm{Y} / \mathrm{T})$ and $(\mathrm{AGV})$, which is another strong point of Shuttle Carrier.

The study on terminal in-yard transportation equipments, however, is very limited to a few researchers to limited extent._The most well-known studies are: estimating the number of $\mathrm{Y} / \mathrm{T}$ and $(\mathrm{AGV})$ in need by simulation method (Choi, 2004; VIS et al., 2001) and Evaluate the capability of terminal in-yard transportation equipment (Ha, et al., 2004). The others are: analyzing types of automated container terminal (Choi, et al., 2005) and studying the effect of terminal yard lay-out on terminal productivity (Choi, et al., 2006).

VIS et al (2003), who studied and analyzed quite

\footnotetext{
* navyshjung@hanmail.net 010-2999-9092

** ready8506@naver.com 051) 410-4912

† Corresponding author, namchan@hhu.ac.kr 051) 410-4336
} 
extensive literature, defined each and every operation process of a container terminal from vessel berth to container stacking and arranged decision-making issues for each process. Regarding transportation equipments, he wrote characteristics and major issues of $(\mathrm{S} / \mathrm{C})$, Multi-trailer system, (AGV) and others in relation with analytical models. Especially, he quoted from Baker(1988) that quay crane productivity can be increased when $(\mathrm{S} / \mathrm{C})$ is adopted.

VIS et al. (2004) is the most similar study to this paper. He estimated the number of Automated Lifting Vehicle (ALV), which can do lift on/off, and Automated Guided Vehicle (AGV), which provides terminal in-yard transportation only, by simulation method. The simulation result showed that (AGV) was needed 38\% more than $(\mathrm{ALV})$. It also showed that terminal design and technical aspects of quay crane have an impact on the number of terminal in-yard transportation equipments needed..

Existing studies on terminal in-yard transportation equipments are rather focused on analyzing performance efficiencies by simulation methods, therefore they seem to have a limitation on economic evaluation. Therefore, this study is to review economical validity of transportation equipments such as (Y/T), (AGV) and upgraded (S/C). To calculate the requested number of equipments, certain scale of container terminal is set with target berth productivity. Therefore, total operation cost was drawn by equipment expenses, labor cost, fuel cost, maintenance expenses and others to propose implications to container terminal operations.

\section{Features of Terminal In-Yard Transportation Equipments}

Until now, major in-yard transportation equipments at container terminals are Yard Tractor-Trailer (Y/T), Straddle Carrier (S/C) and Automated Guided Vehicle $\left.\left(\mathrm{AGV}{ }^{1}\right)\right)<$ Figure1 $>$.
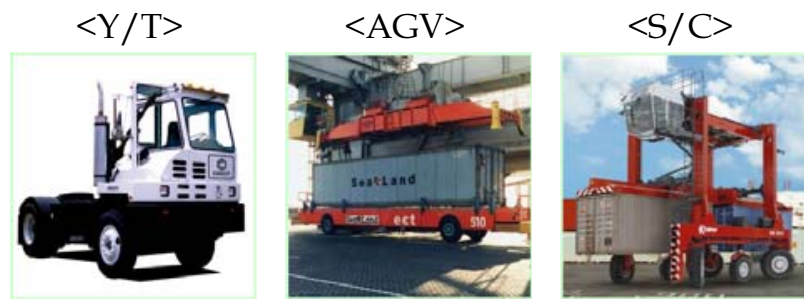

Fig. 1 Transportation equipments in container terminals
(AGV) is currently adopted by the two automated container terminals, ECT Rotterdam, Netherlands and CTA Hamburg, German. It enables reducing labor costs but there is still controversy regarding its technical reliability and relatively low productivity.

Shuttle Carrier, which gets much attention recently, is evaluated as an upgraded Straddle Carrier. Previously (S/C) system was used focusing on container lift on/off due to its lower driving speed than that of $(\mathrm{Y} / \mathrm{T})$. Recently, however, the driving speed of $(\mathrm{S} / \mathrm{C})$ has been improved to the level of $(\mathrm{Y} / \mathrm{T})$, which makes $(\mathrm{S} / \mathrm{C})$ qualified as terminal in-yard transportation equipment. In addition, the lift on/off capability of $(\mathrm{S} / \mathrm{C})$ makes it multi-functional reducing waiting time. In delivering inbound container from vessel, $\mathrm{Y} / \mathrm{T}$ needs to wait for a transfer crane $(\mathrm{T} / \mathrm{C})$ to stack the container. S/C, however, can move on for next job after stacking a container at a given position by itself. APMT Virginia terminal uses Shuttle Carrier System in line with Automated Stacking Crane (ASC).

The strength and weakness of each transportation equipment shall be summarized as seen in $\langle$ Table 1$\rangle$. The productivity of $\mathrm{Y} / \mathrm{T}$ and Shuttle Carrier is higher than that of AGV. This is possible because $\mathrm{S} / \mathrm{C}$ just can lift containers off and move for next assignment, while (AGVs) have to wait (T/C) for lifting containers off. Another important factor, flexibility can be understood in the similar manner. The number of $(\mathrm{S} / \mathrm{C})$ and $(\mathrm{AGV})$ serving a quay crane is only $57 \%$ of $(\mathrm{Y} / \mathrm{T})$, which is a great advantage in terms of operation cost. The capital cost of (AGV) is the highest, that of $(\mathrm{S} / \mathrm{C})$ is in the middle, and that of $\mathrm{Y} / \mathrm{T}$ is the lowest while the operational cost of $(\mathrm{S} / \mathrm{C})$ and $(\mathrm{AGV})$ is low, and that of $(\mathrm{Y} / \mathrm{T})$ is very high.

Table 1 Comparison of transportation Vehicles' performance

\begin{tabular}{c|c|c|c}
\hline Classification & S/C & Y/T & AGV \\
\hline \hline productivity & Good & Good & Bad \\
\hline $\begin{array}{c}\text { Number of equipment } \\
\text { serving a Quay Crane }\end{array}$ & Under 4 & Under 7 & Under 4 \\
\hline capital cost & High & Low & Very High \\
\hline operational costs & Low & Very High & Low \\
\hline flexibility & Good & Good & bad \\
\hline
\end{tabular}

Note : 1) based on experience in several terminals related

1) Refer to VIS F. A. et al.(2003) for information about the work process of each equipment 


\section{Estimation of Terminal In-Yard Transportation Equipments}

\subsection{Scenario Set-up}

This study sets a vessel productivity to draw a requested number of both quay and yard crane. Therefore, the number of terminal in-yard transportation equipment to support the berth and yard operation is calculated.

Terminal environment is $1,100 \mathrm{~m}$ of berth and $700 \mathrm{~m}$ of yard depth. Terminal handling volume starts from 1.5 Million TEU at the initial year and escalates with $10 \%$ annual increase until 2.5 Million TEU. Providing the scenario with more realistic operations, an allowance factor of 1.25 is applied to reflect waiting time and vessel peak time.

Table 2 Handling volume and equipments needed

\begin{tabular}{c|c|c|c|c|c|c|c|c}
\hline \multicolumn{2}{l|}{} & $\begin{array}{c}\text { Year } \\
1\end{array}$ & $\begin{array}{c}\text { Year } \\
2\end{array}$ & $\begin{array}{c}\text { Year } \\
3\end{array}$ & $\begin{array}{c}\text { Year } \\
4\end{array}$ & $\begin{array}{c}\text { Year } \\
5\end{array}$ & $\begin{array}{c}\text { Year } \\
6\end{array}$ & $\begin{array}{c}\text { Year } \\
7\end{array}$ \\
\hline \hline Volume & $\begin{array}{c}1,000 \\
\text { TEU }\end{array}$ & 1,500 & 1,650 & 1,815 & 1,997 & 2,196 & 2,416 & 2,500 \\
\hline $\begin{array}{c}1,000 \\
\text { Moves }\end{array}$ & 888 & 976 & 1,074 & 1,181 & 1,299 & 1,429 & 1,479 \\
\hline $\begin{array}{c}\text { Berth } \\
\text { Productivity }\end{array}$ & 32 & 34 & 36 & 37 & 38 & 38 & 38 \\
\hline $\begin{array}{c}\text { No. of Quay } \\
\text { Crane }\end{array}$ & 8 & 8 & 9 & 9 & 10 & 10 & 10 \\
\hline $\begin{array}{c}\text { No. of Yard } \\
\text { Crane }\end{array}$ & 33 & 37 & 40 & 44 & 49 & 54 & 55 \\
\hline
\end{tabular}

Note: 1) The annual productivity difference is based on ' $V$ ' terminal productivity. Such difference is allowable considering the up skilling of gang, system adaptation, enlargement of calling ships, etc.

2) The followings are applied as : 355 for annual working days, 24 working hours, 0.9 repair factor, 0.96 breakdown factor, 0.95 interference between equipment factor, 0.05 shifting factor, 1,400 moves per ship, and $18 \%$ waiting ratio.

3) The followings are applied as : 18 vans for yard crane productivity, 0.9 repair factor, 0.96 breakdown factor, 0.9 interference factor, 2.5 rehandling factor, $22.37 \%$ checking and repairing empty containers ratio, and $10 \%$ waiting ratio.

\subsection{Estimation of Terminal In-yard Transportation Equipments Needed}

To calculate the number of equipments needed, driving conditions per equipment is set-up as in Table 3 considering capabilities of each equipment. Driving speed of $(\mathrm{S} / \mathrm{C})$ and that of $(\mathrm{Y} / \mathrm{T})$ is the same while speed of $(\mathrm{AGV})$ is $47 \%$ of $(\mathrm{S} / \mathrm{C})$ and $(\mathrm{Y} / \mathrm{T})$.

The waiting time both at vessel and yard are the lowest for $(\mathrm{S} / \mathrm{C})$, while waiting time for $(\mathrm{AGV})$ is the longest because total driving distance and waiting time for switching each other are the longest. (Y/T) as well needs to wait for either quay crane or yard crane to handle a container, while $(\mathrm{S} / \mathrm{C})$ can perform lift on/off, as well as delivering a container by itself.

Driving distance for 1 move is set as average $400 \mathrm{~m}$ for $(\mathrm{Y} / \mathrm{T})$ and $1,800 \mathrm{~m}$ for others presuming $(\mathrm{Y} / \mathrm{T})$ is used at parallel yard lay-out against quay and the others are used at vertical yard lay-out.

Table 3 Equipment driving environment set-up

\begin{tabular}{c|c|c|c}
\hline Equipments & $\mathrm{AGV}$ & $\mathrm{S} / \mathrm{C}$ & $\mathrm{Y} / \mathrm{T}$ \\
\hline \hline Speed $(\mathrm{Km} / \mathrm{h})$ & $14^{1)}$ & $30^{2)}$ & 30 \\
\hline Vessel/Yard Waiting Index & $1.5^{3)}$ & 1.1 & $1.5^{3)}$ \\
\hline Driving Distance(m) & 400 & 400 & 1,800 \\
\hline
\end{tabular}

Note: 1) Refer to the internal information of ECT and CTA

2) Kalmar Press Release, Kalmar makes waves with the launch of its fully-automated Shuttle Carrier, 30, January 2008

3) AGV and $Y / T^{\prime}$ s actual waiting ratio at a terminal, which is $40-50 \%$, was referred.

From quay crane productivity set up previously, total number of equipment were analyzed. Therefore, $\mathrm{Y} / \mathrm{T}$ and $(\mathrm{S} / \mathrm{C})$ were calculated as 0.5 unit per quay crane based on a concept that 1 unit support 2 quay cranes. In real operation, productivity of (AGV) can not be over 34 moves/hr due to its low speed and safety reason. Therefore, calculation for $(\mathrm{AGV})_{\mathrm{S}}$ is based on the productivity as $34 \mathrm{moves} / \mathrm{hr}$.

Table 4 Equipments in need per $\mathrm{C} / \mathrm{C}$ productivity

\begin{tabular}{c|c|c|c}
\hline \multirow{2}{*}{$\begin{array}{c}\text { Q/C Productivity } \\
\text { (moves/h) }\end{array}$} & \multicolumn{3}{|c}{ Equipments In Need Per Quay Crane } \\
\cline { 2 - 4 } & AGV & S/C & Y/T \\
\hline \hline 32 & 4.0 & 3.5 & 6.5 \\
\hline 34 & 4.0 & 3.5 & 6.5 \\
\hline 36 & 4.0 & 3.5 & 7.0 \\
\hline 37 & 4.0 & 3.5 & 7.0 \\
\hline 38 & 4.0 & 3.5 & 7.5 \\
\hline
\end{tabular}

Table 5 shows the total number of equipments in need to handle annual volume and achieve targeted productivity. For the initial year, $(\mathrm{Y} / \mathrm{T})$ and $(\mathrm{Y} / \mathrm{C})$ (Yard Chassis) need 47 and 82 units respectively, while $(\mathrm{S} / \mathrm{C})$ and $(\mathrm{AGV})$ are needed for 22 units and 29. As the annual handling volume increases, the number of equipments needed increases in a fixed rate. 
An Economic Analysis of Transportation Equipments at Container Terminals

Table 5 Annual analysis for equipments in need

\begin{tabular}{c|c|c|c|c|c|c|c}
\hline Equipments & $\begin{array}{c}\text { Year } \\
1\end{array}$ & $\begin{array}{c}\text { Year } \\
2\end{array}$ & $\begin{array}{c}\text { Year } \\
3\end{array}$ & $\begin{array}{c}\text { Year } \\
4\end{array}$ & $\begin{array}{c}\text { Year } \\
5\end{array}$ & $\begin{array}{c}\text { Year } \\
6\end{array}$ & $\begin{array}{c}\text { Year } \\
7\end{array}$ \\
\hline \hline $\mathrm{Y} / \mathrm{T}$ & 47 & 53 & 55 & 62 & 67 & 77 & 80 \\
\hline $\mathrm{Y} / \mathrm{C}$ & 82 & 93 & 97 & 110 & 118 & 136 & 141 \\
\hline $\mathrm{S} / \mathrm{C}$ & 22 & 27 & 28 & 30 & 30 & 34 & 35 \\
\hline $\mathrm{AGV}$ & 29 & 31 & 32 & 34 & 35 & 38 & 40 \\
\hline
\end{tabular}

\section{Economic Analysis of Transportation Equipments}

\subsection{Equipments Procurement Cost}

Purchasing cost of each equipment is 110,000 USD for $\mathrm{Y} / \mathrm{T}, 25,000 \mathrm{USD}$ for $(\mathrm{Y} / \mathrm{C}), 720,000 \mathrm{USD}$ for $(\mathrm{S} / \mathrm{C})$ and 2,000,000 USD for $\left(\mathrm{AGV}^{2}\right.$ ). Manufacturers' Price index is applied at 4.3\%. Double Declining Balance Method is used for equipment depreciation based on life cycle of $(\mathrm{Y} / \mathrm{T})$ and (Y/C) as 10-year and for (S/C) and (AGV) as 20-year. Interest rate is 7\% (payment in 7-year with 3-year grace period $\left.^{3)}\right)$.

The actual cost analysis has been conducted for 20-year operation, yet for the convenience, figures only by 7 th year are provided(Table 6). The annual cash flow of investment on equipments is as follows in Table 7.

Table 6 Annual expense on equipment purchase (Unit: 1,000 USD)

\begin{tabular}{c|c|c|c|c|c|c|c}
\hline & Year1 & Year2 & Year3 & Year4 & Year5 & Year6 & Year7 \\
\hline \hline Y/T & 5,170 & 660 & 220,000 & 770 & 550 & 1,100 & 330 \\
\hline Y/C & 2,050 & 275 & 100 & 325 & 200 & 450 & 125 \\
\hline S/C & 7,220 & 935 & 320 & 1,095 & 750 & 1,550 & 455 \\
\hline AGV & 15,840 & 3,600 & 720 & 1,440 & - & 2,880 & 720 \\
\hline
\end{tabular}

Table 7 Annual cash flow of investment of equipments

(Unit: 1,000 USD)

\begin{tabular}{c|c|c|c|c|c|c|c|c|c|c}
\hline & $\begin{array}{c}\text { Year } \\
1\end{array}$ & $\begin{array}{c}\text { Year } \\
2\end{array}$ & $\begin{array}{c}\text { Year } \\
3\end{array}$ & $\begin{array}{c}\text { Year } \\
4\end{array}$ & $\begin{array}{c}\text { Year } \\
5\end{array}$ & $\begin{array}{c}\text { Year } \\
6\end{array}$ & $\begin{array}{c}\text { Year } \\
7\end{array}$ & $\begin{array}{c}\text { Year } \\
8\end{array}$ & $\begin{array}{c}\text { Year } \\
9\end{array}$ & $\begin{array}{c}\text { Year } \\
10\end{array}$ \\
\hline \hline \multirow{3}{*}{$\begin{array}{c}\text { Y/T+ } \\
\text { Y/C }\end{array}$} & 863 & 863 & 863 & 2,623 & 2,500 & 2,377 & 2,254 & 2,130 & 2,007 & 1,884 \\
\cline { 2 - 13 } & Y11 & Y12 & Y13 & Y14 & Y15 & Y16 & Y17 & Y18 & Y19 & Y20 \\
\cline { 2 - 12 } & 1,314 & 1,314 & 1,314 & 3,997 & 3,809 & 3,621 & 3,434 & 3,246 & 3,058 & 2,870 \\
\hline \multirow{3}{*}{$\begin{array}{c}\text { Year } \\
1\end{array}$} & $\begin{array}{c}\text { Year } \\
2\end{array}$ & $\begin{array}{c}\text { Year } \\
3\end{array}$ & $\begin{array}{c}\text { Year } \\
4\end{array}$ & $\begin{array}{c}\text { Year } \\
5\end{array}$ & $\begin{array}{c}\text { Year } \\
6\end{array}$ & $\begin{array}{c}\text { Year } \\
7\end{array}$ & $\begin{array}{c}\text { Year } \\
8\end{array}$ & $\begin{array}{c}\text { Year } \\
9\end{array}$ & $\begin{array}{c}\text { Year } \\
10\end{array}$ \\
\hline \hline \multirow{2}{*}{ S/C } & 1,764 & 1,764 & 1,764 & 5,364 & 5,112 & 4,860 & 4,608 & 4,356 & 4,104 & 3,852 \\
\hline AGV & 5,600 & 5,600 & 5,600 & 17,29 & 16229 & 15,429 & 1462 & 13829 & 13,029 & 12229 \\
\hline
\end{tabular}

2) The price of $\mathrm{Y} / \mathrm{T}, \mathrm{Y} / \mathrm{C}$ and $\mathrm{S} / \mathrm{C}$ are the average of market prices in 2009. For the AGV vehicle purchase expense and inflation rate were applied with reference to a terminal.

3) The lifespan of equipments is based on the data provided by its manufacturer.

\subsection{Labor Cost}

Annual labor cost is total 47,760 USD including payment to driver, direct and indirect management cost. Operation shift is 4 -shift, which is the most common practice at European and North American Terminals. Operation condition is 2 -hour work and 30 -minute rest.

Table 8 Equipment drivers in need

\begin{tabular}{c|c|c|c|c|c|c|c}
\hline Division & $\begin{array}{c}\text { Year } \\
1\end{array}$ & $\begin{array}{c}\text { Year } \\
2\end{array}$ & $\begin{array}{c}\text { Year } \\
3\end{array}$ & $\begin{array}{c}\text { Year } \\
4\end{array}$ & $\begin{array}{c}\text { Year } \\
5\end{array}$ & $\begin{array}{c}\text { Year } \\
6\end{array}$ & $\begin{array}{c}\text { Year } \\
7\end{array}$ \\
\hline \hline $\mathrm{Y} / \mathrm{T}$ & 234 & 264 & 276 & 312 & 335 & 387 & 400 \\
\hline $\mathrm{S} / \mathrm{C}$ & 110 & 134 & 139 & 149 & 152 & 168 & 174 \\
\hline
\end{tabular}

\subsection{Cost Analysis for Productivity Performance}

While our targeted berth productivity is 38 moves per crane per hour, the maximum berth productivity of (AGV) is 34 moves per crane per hour, thus additional cost analysis due to the lower productivity is requested. Therefore, the scenario is set as follows : 5,000 TEU vessel with 4 gangs consisting of 3 lashers and 2 tallyman, 1,400 moves per vessel, 0.96 for equipment interference ratio for quay crane, 1.5 quay crane driver shift turn factor, 6 USD/TEU vessel chartering cost, $70 \mathrm{USD} /$ box stevedoring income, and $70 \%$ berth occupancy ratio.

\subsection{Cost Analysis Result}

From the established scenario in previous section, detailed operation costs are calculated as in Table 9. (AGV) doesn't require labor cost since it is automated. Fuel consumption cost has been analyzed reflecting 1.1 USD per 1 liter for total driving distance. Maintenance cost has been reflected with $1.1 \%$ of equipment depreciation, which is a common maintenance cost level at container terminals in Busan Port.

Table 9 Equipment cost analysis

(unit : 1,000 USD)

\begin{tabular}{c|c|c|c|c|c|c|c|c}
\hline & & $\begin{array}{c}\text { Year } \\
1\end{array}$ & $\begin{array}{c}\text { Year } \\
2\end{array}$ & $\begin{array}{c}\text { Year } \\
3\end{array}$ & $\begin{array}{c}\text { Year } \\
4\end{array}$ & $\begin{array}{c}\text { Year } \\
5\end{array}$ & $\begin{array}{c}\text { Year } \\
6\end{array}$ & $\begin{array}{c}\text { Year } \\
7\end{array}$ \\
\hline \hline \multirow{2}{*}{ Labor Cost } & $\mathrm{Y} / \mathrm{T}$ & 9,369 & 11,022 & 12,015 & 14152 & 15871 & 19,055 & 20,599 \\
\cline { 2 - 9 } & $\mathrm{S} / \mathrm{C}$ & 4,414 & 5,572 & 6,063 & 6,767 & 7,215 & 8,278 & 8,935 \\
\hline \multirow{4}{*}{$\begin{array}{c}\text { Fuel } \\
\text { Consumption }\end{array}$} & $\mathrm{Y} / \mathrm{T}$ & 1,079 & 1,187 & 1,306 & 1,436 & 1,580 & 1,738 & 1,799 \\
\cline { 2 - 9 } & $\mathrm{S} / \mathrm{C}$ & 493 & 543 & 597 & 677 & 722 & 795 & 822 \\
\cline { 2 - 9 } & $\mathrm{AGV}$ & 743 & 817 & 898 & 988 & 1,087 & 1,196 & 1,238 \\
\hline \multirow{4}{*}{ Depreciation } & $\mathrm{Y} / \mathrm{T}$ & 1,836 & 1,836 & 1,836 & 1,836 & 1,836 & 1,836 & 1,836 \\
\cline { 2 - 9 } & $\mathrm{S} / \mathrm{C}$ & 1,877 & 1,877 & 1,877 & 1,877 & 1,877 & 1,877 & 1,877 \\
\cline { 2 - 9 } & $\mathrm{AGV}$ & 5,960 & 5,960 & 5,960 & 5,960 & 5,960 & 5,960 & 5,960 \\
\hline \multirow{4}{*}{ Maintenance } & $\mathrm{Y} / \mathrm{T}$ & 202 & 211 & 220 & 229 & 239 & 249 & 260 \\
\cline { 2 - 9 } & $\mathrm{S} / \mathrm{C}$ & 21 & 22 & 22 & 23 & 24 & 25 & 27 \\
\cline { 2 - 9 } & $\mathrm{AGV}$ & 1,311 & 1,368 & 1,426 & 1,488 & 1,502 & 1,618 & 1,688 \\
\hline
\end{tabular}


In addition to the cost analyzed above, (AGV) requires additional cost due to its lower productivity performance. As mentioned before the maximum productivity of (AGV) is evaluated as no more than 34 moves per crane per hour. The difference between targeted productivity, 38 moves/crane/hour, and maximum productivity of (AGV), 34 causes additional cost such as direct labor cost, shipping liners cost, and opportunity cost to terminal operators. Considering factors for the analysis is the same as initial preconditions. Lower productivity of $(\mathrm{AGV})$ is analyzed to request additional working hours up to 1.1 hour.

Table 10 Analysis of direct \& indirect cost for productivity difference

(unit : 1,000 USD)

\begin{tabular}{c|c|c|c|c|c|c|c}
\hline Division & $\begin{array}{c}\text { Year } \\
1\end{array}$ & $\begin{array}{c}\text { Year } \\
2\end{array}$ & $\begin{array}{c}\text { Year } \\
3\end{array}$ & $\begin{array}{c}\text { Year } \\
4\end{array}$ & $\begin{array}{c}\text { Year } \\
5\end{array}$ & $\begin{array}{c}\text { Year } \\
6\end{array}$ & $\begin{array}{c}\text { Year } \\
7\end{array}$ \\
\hline \hline $\begin{array}{c}\text { Volume } \\
(1,000 \text { Moves })\end{array}$ & 888 & 976 & 1,074 & 1,181 & 1,299 & 1,429 & 1,479 \\
\hline Annual Vessels & 634 & 697 & 767 & 844 & 928 & 1,021 & 1,057 \\
\hline $\begin{array}{c}\text { Shipping Lines } \\
\text { Cost }^{1)}\end{array}$ & 904 & 994 & 1,094 & 1,203 & 1,323 & 1,456 & 1,507 \\
\hline $\begin{array}{c}\text { Terminal Direct } \\
\text { Cost }\end{array}$ & 99 & 109 & 120 & 132 & 145 & 160 & 165 \\
\hline $\begin{array}{c}\text { Terminal } \\
\text { Opportunity Cost }\end{array}$ & 539 & 592 & 652 & 717 & 789 & 867 & 898 \\
\hline Total & 1,542 & 1,696 & 1,865 & 2,052 & 2,257 & 2,483 & 2,569 \\
\hline
\end{tabular}

Note: 1) Hire base is applied

2) Lashing, inspection labor, and overtime expense for crane drivers 3) It refers to the expense incurred by additional working hour preventing other ships from berthing alongside the quay. The occupation ratio of $70 \%$ and the handling expense of $\$ 70$ per box were applied.

Analysis results show that (AGV) is more economical over other equipments from Year 7 based on the given scenario. $\mathrm{S} / \mathrm{C}$ is the most economical equipment up to Year 6 , yet the cost exceeds that of (AGV) by $4.5 \%$ followed by continuous increase. After all, the preference of (AGV) versus $\mathrm{S} / \mathrm{C}$ seems to depend on technical reliability and operational labor cost.

Table 11 Total cost per equipments (unit : 1,000 USD)

\begin{tabular}{c|c|c|c|c|c|c|c|c|c|c}
\hline & $\begin{array}{c}\text { Year } \\
1\end{array}$ & $\begin{array}{c}\text { Year } \\
2\end{array}$ & $\begin{array}{c}\text { Year } \\
3\end{array}$ & $\begin{array}{c}\text { Year } \\
4\end{array}$ & $\begin{array}{c}\text { Year } \\
5\end{array}$ & $\begin{array}{c}\text { Year } \\
6\end{array}$ & $\begin{array}{c}\text { Year } \\
7\end{array}$ & $\begin{array}{c}\text { Year } \\
8\end{array}$ & $\begin{array}{c}\text { Year } \\
9\end{array}$ & $\begin{array}{c}\text { Year } \\
10\end{array}$ \\
\hline \hline $\mathrm{Y} / \mathrm{T}$ & 12,487 & 14,256 & 15,37 & 17,654 & 19,52 & 22,908 & 24,494 & 25,391 & 26,327 & 27,308 \\
\hline $\mathrm{S} / \mathrm{C}$ & 6,805 & 8,014 & 8,550 & 9,324 & 9,839 & 10,95 & 11,661 & 12,047 & 12,49 & 12,868 \\
\hline $\mathrm{AGV}$ & 9,555 & 9,840 & 10,150 & 10,488 & 10,856 & 11,55 & 11,450 & 11,527 & 11,608 & 11,682 \\
\hline
\end{tabular}

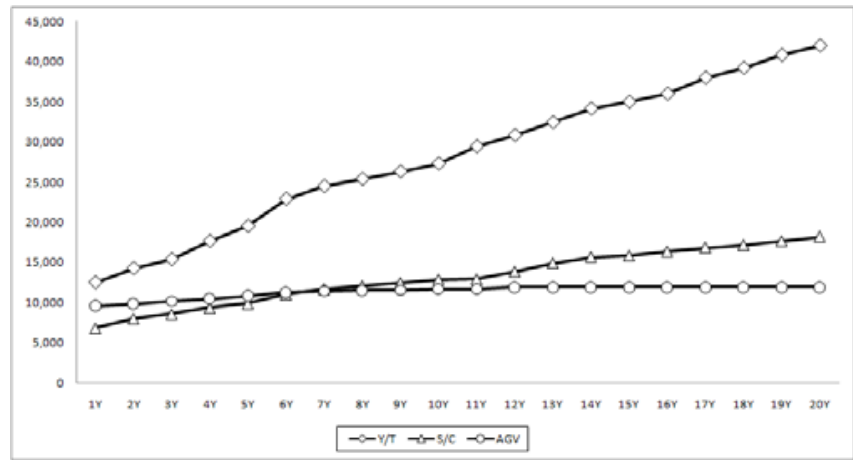

Fig. 2 Total cost per equipments (unit : 1000 USD)

As previously stated, the economics of (AGV) depends on labor cost. We, therefore, analyze total cost of equipments per labor cost level. The analysis result shows that $(\mathrm{AGV})$ is economical for terminals where annual payment of labor cost is over 55,000 USD. For the terminals whose annual labor cost is lower than 55,000 $\mathrm{USD}, \mathrm{S} / \mathrm{C}$ system is preferable from economical perspective.

Table 12 cost analysis per annual labor cost (unit : 1,000 USD)

\begin{tabular}{c|c|c|c|c|c|c|c}
\hline $\begin{array}{c}\text { Amal } \\
\text { Labor } \\
\text { Cost }\end{array}$ & $\begin{array}{c}20,000 \\
\text { USD }\end{array}$ & $\begin{array}{c}25,000 \\
\text { USD }\end{array}$ & $\begin{array}{c}30,000 \\
\text { USD }\end{array}$ & $\begin{array}{c}35,000 \\
\text { USD }\end{array}$ & $\begin{array}{c}40,000 \\
\text { USD }\end{array}$ & $\begin{array}{c}45,000 \\
\text { USD }\end{array}$ & $\begin{array}{c}50,000 \\
\text { USD }\end{array}$ \\
\hline Y/T & 11,895 & 13,895 & 15,895 & 17,895 & 19,895 & 21,895 & 23,895 \\
\hline S/C & 6,206 & 7,076 & 7,946 & 8,816 & 9,686 & 10,556 & 11,426 \\
\hline AGV & 11,499 & 11,582 & 11,669 & 11,759 & 11,853 & 11,949 & 12,050 \\
\hline
\end{tabular}

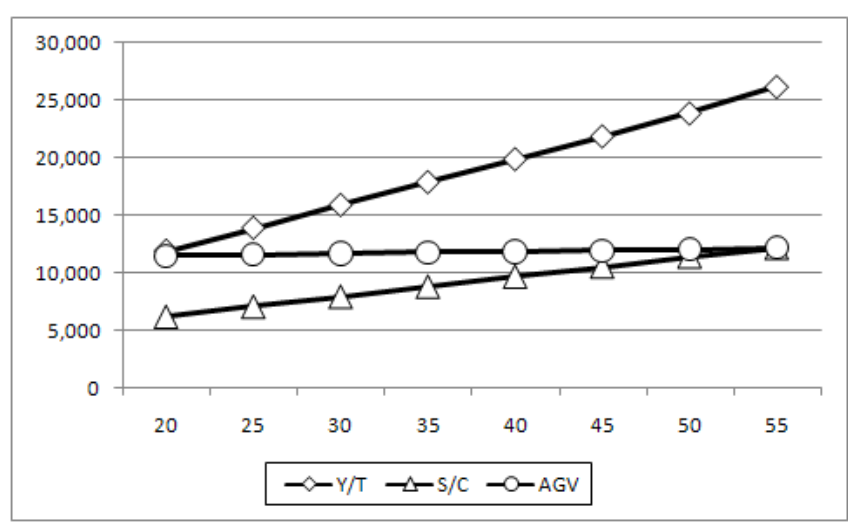

Fig. 3 Cost analysis per annual labor cost (Unit : 1,000 USD)

\section{Conclusion}

Most of the previous studies regarding container terminal productivity and handling equipments have been focusing on quay cranes. However, the importance of yard-to-berth transportation and yard productivity needs to be highlighted 
because berth productivity is limited unless efficient yard-to-berth transportation and corresponding yard productivity are provided.

In the past, $(\mathrm{S} / \mathrm{C})$ system was used mainly for container stacking and lifting on/off purposes due to its lower running speed. Recently, however, the improved running speed of $(\mathrm{S} / \mathrm{C})$ to that of $(\mathrm{Y} / \mathrm{T})$ made it relevant as terminal in-yard transportation equipment. In addition to this, the multi-function of $(\mathrm{S} / \mathrm{C})$, container lift on/off, as well as container transportation, is another strong-point of $(\mathrm{S} / \mathrm{C})$ over $(\mathrm{Y} / \mathrm{T})$. While $(\mathrm{Y} / \mathrm{T})$ has to wait for a $(\mathrm{T} / \mathrm{C})$ to handle and stack containers at yard, (S/C) can discharge/stack a container at a given position and move for next job, thus reducing waiting time dramatically.

Cost analysis also showed that (S/C) over-performs $(\mathrm{Y} / \mathrm{T})$, which is overlooked by most of container terminals currently using (Y/T). When compared to (AGV), (S/C) is economical up to the 6th year after terminal opening and its operation cost goes up continuously. However, the controversy on technical reliability and lower productivity of (AGV) need to be considered in accordance with the economical factor. For container terminals which pay higher labor cost including the ones in Korea need to do a detailed analysis on (AGV) operation from economical and technical perspective since (AGV) seems to be economical at terminals where annual payment of labor cost is over 55,000 USD.

This study is limited to the economic analysis of terminal in-yard transportation equipments with directly related to the terminal environment scenario, therefore, more comprehensive study on overall terminal operation systems is in the hand of future researchers.

\section{References}

[1] APM Terminals Virginia (www.apmterminals.com)

[2] Baker, C.(1998), "High time for straddles", Cargo systems, October, 1998, pp.23-26.

[3] Brisbane port (www.portbris.com.au)

[4] Choi, H.R., D.H. Yoo, N.K. Park, B.J. Park, H.K. Kwon(2005), "A Study on the Strategy Development of Automated Container Terminal: based on the cases of existing ACT, Journal of Shipping and Logistics, The korean Association of Shipping and Logistics, Vol.47, pp.59-78.

[5] Choi, S.H, T.Y. Ha(2006), "A Study on Productivity Analysis by Yard Layout of Container Terminal", Ocean Policy Research, Korea Maritime Institute,
Vol.21. No.1, pp.151-183.

[6] Choi, Y.S., W.S. Kim, T.Y. Ha(2004), "An Estimate of the Required Number of Yard Tractor in Container Terminal", Journal of Navigation and Port Research, Korean Institute of Navigation and Port Research, Vol.28 , No.6, pp.549-555.

[7] Ha, T.Y., Y.S. Choi, W.S. .Kim(2004), "Simulation-based Evaluation of AGV Operation at Automated Container Terminal", Journal of Navigation and Port Research, Korean Institute of Navigation and Port Research, Vol. 28, N.10, pp891-897.

[8] Kalmar(2008), Press Release, Karmar makes waves with the launch of its fully-automated Shuttle Carrier, Kalmar Press Release, 30, January 2008.

[9] Nam, K.C., K.S. Kwak and M.S. Yu(2002), "Simulation Study of Container Terminal Performance", Journal of Waterway, Port, Coastal \& Ocean Eng., ASCE, Vol.128, No.3, pp.126-132.

[10] Vis, Iris F. A., De Koster, R., , K.J., L.W.P Roodbergen. Peeters(2001), "Determination of the number of automated guided vehicles required at a semi-automated container terminal", Journal of Operation Society, Vol.52, pp.409-417.

[11] Vis, Iris F. A., Rene de Koster(2003), "Transshipment of containers at a container terminal: An overview", European Journal of Operational Research, Vol.147, pp.1-16.

[12] Vis, Iris F. A., smael Harika(2004), "Comparison of vehicle types at an automated container terminal", OR Spectrum, Vol.26, pp.117-143.

Received 1 February 2011

Revised 27 March 2011

Accepted 30 March 2011 